\title{
Tuotantoeläinten hyvinvointituki eräissä Euroopan maissa
}

\author{
Kauko Koikkalainen ja Antti Miettinen
}

MTT Taloustutkimus, Luutnantintie 13,00410 Helsinki, etunimi.sukunimi@mtt.fi

\section{Tiivistelmä}

Vuosiksi 2007-2013 laadittujen maaseudun kehittämisohjelmien hyväksymisen myötä tuotantoeläinten hyvinvoinnin edistäminen tuli vapaaehtoiseksi maaseudun kehittämistoimenpiteeksi Suomessa ja muutamissa muissa Euroopan unionin jäsenmaissa. Näin ollen on mielenkiintoista vertailla, millä tavoin tuotantoeläinten hyvinvointia edistetään ja miten eläinten hyvinvointitoimenpide on pantu täytäntöön eri maissa.

Vertailevassa tutkimuksessa tarkastelemme eläinten hyvinvointitoimenpiteen tavoitteita ja sisältöä, mitä tuotantoeläimiä toimenpiteet koskevat, mitä toimenpiteitä tuen saamiseksi edellytetään ja kuinka suuria ovat viljelijöille maksettavat korvaukset toimenpiteiden aiheuttamista lisäkustannuksista ja tulonmenetyksistä. Suomessa vuonna 2008 käyttöön otettu eläinten hyvinvointitoimenpide koostuu perusja lisäehdoista ja toimenpiteet voivat kohdistua tilalla oleviin nautoihin tai sikoihin. Tuki on eläinyksikköperusteinen. Perusehdoista maksettavan tuen suuruus on nautatiloilla 17,50 euroa/eläinyksikkö ja sikatiloilla 5,00 euroa/eläinyksikkö. Suomen lisäksi tarkastelun kohteina ovat Emilia-Romagnan alue Italiassa, Kastilian ja Léonin itsehallintoalue Espanjassa, Mecklenburg-EtuPommerin osavaltio Saksassa ja Skotlanti Isossa-Britanniassa. Alkuperäisestä suunnitelmasta poiketen Kreikka jouduttiin jättämään tarkastelun ulkopuolelle, koska sieltä ei saatu riittävän yksityiskohtaisia tietoja eläinten hyvinvointituesta.

Tutkimuksessa on hyödynnetty AGRIGRID-tutkimushankkeessa kertynyttä aineistoa eläinten hyvinvointia edistävistä tuista. AGRIGRID on EU:n tutkimuksen kuudennesta puiteohjelmasta rahoitettu tutkimushanke, ja sen varsinaisena tavoitteena on EU:n maaseudun kehittämistoimenpiteiden kustannuslaskennan yhtenäistäminen. Edellä mainittujen maiden ja alueiden lisäksi hankkeessa ovat mukana myös Liettua, Puola ja Tšekin tasavalta, mutta näissä maissa ei ole käytössä eläinten hyvinvointia edistäviä tukia. Kesällä 2007 hankkeessa kartoitettiin maaseudun kehittämistoimenpiteitä kyselylomakkeilla sekä tutkimalla maaseudun kehittämisohjelmaluonnoksia ja haastattelemalla laskennan asiantuntijoita. Tällöin kertyi paljon tietoa muun muassa eläinten hyvinvointitoimenpiteiden sisällöistä.

Eläinten hyvinvointitoimenpiteen tarkoituksena on kaikissa tarkastelluissa maissa tuotantoeläinten hyvinvoinnin ja terveyden lisääminen sekä eläinten hyvinvointiin ja terveyteen liittyvien julkishyötyjen tuottaminen. Eri maiden tukiehdot ovat vaihtelevia, eikä selkeää yhteistä linjaa ole vielä muotoutunut.

Tuella korvataan viljelijöille eläinten hyvinvoinnin tuottamisesta aiheutuneet lisäkustannukset ja tulonmenetykset ja joissakin maissa (kuten Suomessa) myös transaktiokustannukset. Tuen avulla pyritään varmistamaan, että kotieläintuotannon kannattavuus ja kansainvälinen kilpailukyky eivät heikkene eläinten hyvinvointia edistävien toimenpiteiden seurauksena. Tutkimuksen tulokset asemoivat eläinten hyvinvointitoimenpiteet eurooppalaiseen kilpailuympäristöön, lisäävät tietoa uudesta maaseudun kehittämistoimenpiteestä sekä auttavat tuen ja tukitoimenpiteiden edelleen kehittämisessä.

Asiasanat: eläinten hyvinvointi, maaseudun kehittäminen 


\section{Johdanto}

Tuotantoeläinten hyvinvoinnin perustan muodostavat riittävä veden ja ravinnon saanti, eläinten hyvä terveys, tarkoituksenmukaiset tuotanto-olosuhteet ja asiallinen eläinten käsittely (Valros ym., 2005). Hyvinvoiva eläin voi tyydyttää myös lajinmukaisia käyttäytymistarpeitaan (Valros, 2005). Tutkimusten mukaan (Kaustell, 2000; Raussi \& Hänninen, 2005) eläinten hoitaja on tärkein yksittäinen eläinten hyvinvointiin vaikuttava tekijä, mutta tuotantoeläinten hyvinvointiin vaikutetaan monella tavalla myös Euroopan unionin ja sen jäsenvaltioiden tahoilta.

Eräs uusimmista maaseudun kehittämistoimenpiteistä (toimenpide 215) on tässä tutkimuksessa tarkasteltava vapaaehtoinen eläinten hyvinvointia edistävä tuki. Se kuuluu Euroopan unionin maaseudun kehittämisessä toimintalinjalle 2 (ympäristön ja maaseudun parantaminen) ja sen säädösperustana on kaikissa EU-maissa maaseudun kehittämisasetus (neuvoston asetus (EY) N:o 1698/2005) ja komission toimeenpanoasetus (komission asetus (EY) N:o 1974/2006).

Eläinten hyvinvointituella korvataan viljelijöille eläinten hyvinvoinnin lisäämisestä aiheutuneet nettokustannukset ja -tulonmenetykset. Nettokustannuksia ja -tulonmenetyksiä laskettaessa hyvän maatalouden ja ympäristön sekä voimassa olevan lainsäädännön vaatimusten ylittämisestä aiheutuvista kustannuksista ja tulonmenetyksistä vähennetään pois viljelijän toimenpiteen seurauksena saamat hyödyt joita syntyy, koska eläinten kohonnut hyvinvointi ja terveys lisäävät tuotosta ja parantavat tuotoksen laatua. Laskentaperiaate on siis samanlainen kuin esimerkiksi maatalouden ympäristötuessa ja toimenpiteen tarkoituksena on eläinten hyvinvoinnin lisääntymisen kautta kaikille tulevien julkishyötyjen tuottaminen. Lisäksi voidaan korvata viljelijöille syntyneet transaktiokustannukset. Transaktiokustannuksilla tarkoitetaan kustannuksia, jotka liittyvät itse transaktion toteutumiseen eivätkä liity suoraan itse sitoumuksen toteuttamiseen.

Tässä tutkimuksessa tarkastellaan ja vertaillaan eläinten hyvinvointitoimenpiteiden sisältöä Suomen lisäksi Emilia-Romagnan alueella Italiassa, Kastilian ja Léonin itsehallintoalueella Espanjassa, Mecklenburg-Etu-Pommerin osavaltiossa Saksassa sekä Skotlannissa Isossa-Britanniassa. Lisäksi selvitetään mitä tuotantoeläimiä toimenpiteet koskevat, mitä toimenpiteitä tuen saamiseksi edellytetään ja kuinka suuria ovat viljelijöille maksettavat korvaukset toimenpiteiden aiheuttamista lisäkustannuksista ja tulonmenetyksistä.

Mainittakoon, että Suomen naapurivaltioista Ruotsi ei ole sisällyttänyt eläinten hyvinvointitoimenpidettä maaseudun kehittämisohjelmaansa. Se sijaan Virossa nautojen, lampaiden, vuohien ja hevosten laiduntamista voidaan ohjelmakaudella 2007-2013 tukea eläinten hyvinvointituella.

\section{Aineisto ja menetelmät}

Tutkimuksessa on hyödynnetty AGRIGRID-tutkimushankkeessa (http://www.macaulay.ac.uk/agrigrid/) kertynyttä aineistoa eläinten hyvinvointia edistävistä tuista. AGRIGRID on EU:n tutkimuksen kuudennesta puiteohjelmasta rahoitettu tutkimushanke, ja sen varsinaisena tavoitteena on EU:n maaseudun kehittämistoimenpiteiden kustannuslaskennan yhtenäistäminen. Hankkeessa ovat mukana seuraavat maat ja alueet: Italia, Kreikka, Liettua, Saksa, Skotlanti, Suomi ja Tšekin tasavalta. Lisäksi tapaustutkimuksia tehdään Espanjassa ja Puolassa.

Kesällä 2007 hankkeessa kartoitettiin maaseudun kehittämistoimenpiteitä kyselylomakkeilla sekä tutkimalla maaseudun kehittämisohjelmaluonnoksia ja haastattelemalla laskennan asiantuntijoita. Kustannusten ja tulonmenetysten laskennassa tarvittavien tietojen lisäksi tällöin kertyi paljon tietoa muun muassa eläinten hyvinvointitoimenpiteiden sisällöistä. Saatua tietoa päätettiin hyödyntää tässä tutkimuksessa. On kuitenkin huomattava, että osa kyselyihin saaduista vastauksista on ennakkotietoja tai osin puutteellisia, sillä läheskään kaikkien maiden ja alueiden maaseudun kehittämisohjelmia ei oltu hyväksytty vielä kyselyiden tekoaikana. 


\section{Tulokset ja tulosten tarkastelu}

Tässä luvussa käydään läpi ja vertaillaan eläinten hyvinvointitoimenpiteiden sisältöä viidessä Euroopan maassa.

\section{Toimenpiteen voimaantulo ja tuettavat eläinlajit}

Suomessa eläinten hyvinvointituki otettiin käyttöön vuonna 2008 ja hyvinvointia edistävät toimenpiteet voivat kohdistua tilalla oleviin nautoihin tai sikoihin. Sopimuksen tehneet viljelijät sitoutuvat viideksi vuodeksi toimenpiteen edellyttämien velvoitteiden noudattamiseen valitsemiensa eläinlajien osalta.

Vertailtavista maista ja alueista eläinten hyvinvointia edistävä tuki oli käytössä Skotlannissa ja Mecklenburg-Etu-Pommerin osavaltiossa Saksassa jo edellisellä ohjelmakaudella (2000-2006). Muut tarkasteltavat maat ja alueet - Emilia-Romagnan alue Italiassa sekä Kastilian ja Léonin itsehallintoalue Espanjassa - ottivat tuen käyttöön vasta ohjelmakaudella 2007-2013.

Suomessa ja Mecklenburg-Etu-Pommerin osavaltiossa eläinten hyvinvointituen piiriin kuuluvat naudat ja siat. Emilia-Romagnan alueella tuen piirissä ovat lypsykarja, lihakarja, siat, lampaat, kanat ja broilerit ja Kastilian ja Léonin itsehallintoalueella kanat, broilerit ja emakot. Skotlannissa puolestaan siat ja siipikarja eivät kuulu tuettaviin eläinlajeihin vaan tuki on tarkoitettu naudoille ja lampaille.

\section{Vähimmäisvaatimukset ja korvattavat toimenpiteet}

Euroopan unionin jäsenvaltioissa varmistetaan lainsäädännön avulla, että eläintilojen, kasvatusolosuhteiden, hoidon ja kohtelun eläinsuojelulliset vähimmäisvaatimukset täyttyvät. EU:ssa on annettu kaikkien tuotantoeläinten suojelua koskevan direktiivin (98/58/EY) lisäksi myös vasikoiden, sikojen ja kanojen suojelun vähimmäisvaatimuksia koskevat direktiivit (91/629/ETY, 91/630/ETY ja 99/74/EY). Jäsenvaltioissa direktiivien sisältö on saatettu voimaan kansallisella lainsäädännöllä. Kansallisessa lainsäädännössä voidaan myös asettaa EU-direktiivejä tiukempia vaatimuksia. Suomessa tuotantoeläinten hyvinvointia koskevista vaatimuksista on säädetty eläinsuojelulaissa ja -asetuksessa sekä maa- ja metsätalousministeriön eläinlajikohtaisissa päätöksissä ja asetuksissa. Eläinten pitoon liittyvän lainsäädännön lisäksi eläinten hyvinvointiin liittyvää lainsäädäntöä on myös eläinkuljetuksista ja teurastuksesta.

Vuoden 2007 alusta tuotantoeläinten eläinsuojeluvaatimuksia on EU:ssa alettu valvoa osana maataloustukien täydentäviä ehtoja. Täydentävät ehdot jakautuvat kahteen osaan (lakisääteiset hoitovaatimukset sekä hyvän maatalouden ja ympäristön vaatimukset) ja perustuvat voimassaolevan lainsäädännön vaatimuksiin. Täydentävien ehtojen noudattaminen on kaikissa EU-maissa edellytys tilatuen, luonnonhaittakorvauksen (LFA-tuen), maatalouden ympäristötuen ja eläinten hyvinvointituen täysimääräiselle saamiselle.

Eläinten hyvinvointituki voi kussakin EU-maassa kattaa ainoastaan lainsäädännön vähimmäisvaatimusten yli menevistä toimenpiteistä aiheutuvat kustannukset ja tulonmenetykset sekä transaktiokustannukset. Neuvoston asetuksen (EY) N:o 1698/2005 mukaan vuotuinen eläinyksikkökohtainen enimmäistukitaso on 500 euroa/eläinyksikkö.

Kiinteitä investointikustannuksia ei voida korvata eläinten hyvinvointituella, vaan niitä varten on olemassa erillisiä investointitukia.

\section{Toimenpiteeseen sitoutumiseen ja tuen maksamiseen liittyviä edellytyksiä}

Suomessa viljelijän tai hänen puolisonsa tulee (pääsääntöisesti) olla 18-65-vuotias, jotta hän voi solmia sopimuksen eläinten hyvinvointitoimenpiteestä. Lisäksi tukeen sitoutuneella tilalla tulee olla vähintään 10 eläinyksikköä nautoja tai sikoja koko sitoumuskauden ajan.

Muissa tarkastelluissa maissa ei ole vastaavanlaisia viljelijän ikäedellytyksiä kuin Suomessa. Emilia-Romagnan alueella tukeen sitoutuneella tilalla tulee olla vähintään 6 eläinyksikköä ja Skotlannissa vähintään 4 eläinyksikköä tuettavia eläinlajeja.

Lisäksi Kastilian ja Léonin itsehallintoalueella Espanjassa toimenpiteeseen sitoutumisen edellytyksenä on, että tuen hakija ei ole syyllistynyt eläinten hyvinvointisäännösten rikkomiseen ja että eläinjätteen käsittelystä tilalla on huolehdittu asianmukaisesti. 


\section{Toimenpiteen sisältö ja rakenne sekä tukitasot}

Suomessa eläinten hyvinvointituki koostuu perusehdoista ja lisäehdoista. Perusehtojen toimenpiteet on osittain eriytetty nautojen ja sikojen välillä ja perusehtojen päätavoite on eläinten terveyden ja turvallisuuden edistäminen. Perusehtoihin kuuluu muun muassa tuotantoeläinten terveydenhuollon kansallisen tason vaatimusten täyttäminen. Ensimmäisellä eläinlääkärin käynnillä tehdään viljelijän ja eläinlääkärin välinen kirjallinen eläinten terveydenhuoltosopimus ja yksityiskohtaisempi terveydenhuoltosuunnitelma päivitetään sitoumuskauden aikana vuosittain. Lisäksi huolehditaan muun muassa tilan tautisuojauksesta ja turvallisesta eläinten ja rehujen tuonnista ulkomailta. Perusehtoihin kuuluu myös varautuminen sähkökatkoksiin. Perusehtojen tuki on naudoille 17,50 euroa/eläinyksikkö ja sioille 5,00 euroa/eläinyksikkö. Perusehtojen lisäksi viljelijä voi valita enintään kaksi lisäehtoa. Lisäehdot vaikuttavat suoraan tilan tuotanto-olosuhteisiin. Ne sisältävät yksityiskohtaisia vaatimuksia mm. karsinaja pito-olosuhteiden parantamisesta, laidunnuksesta ja jaloittelusta sekä emakoiden ja ensikoiden tiineytyksestä. Lisäehtojen tukitaso vaihtelee toimenpiteittäin 1,53 eurosta/eläinyksikkö 21,06 euroon/eläinyksikkö. Lisäksi on säädetty, että tilakohtainen eläinten hyvinvointituki ei voi Suomessa ylittää 5000 euroa vuodessa.

Emilia-Romagnan alueella Italiassa eläinten hyvinvointitoimenpiteen piiriin kuuluvat lypsykarja, lihakarja, lampaat, kanat, broilerit ja siat. Jokaiselle eläinryhmälle on valittavissa viisi toimenpidettä:

A) maatilan hoidon parantaminen

B) tuotantorakennusten ja kasvatusjärjestelmien parantaminen

C) ympäristövalvonnan parantaminen

D) ruokinnan ja veden saannin parantaminen

E) puhtauteen, terveyteen ja eläinten käyttäytymiseen liittyvien näkökohtien parantaminen Toimenpiteiden tukitasot vaihtelevat huomattavasti eläinryhmittäin (eläinyksikkökohtaiset tuet ovat korkeimmat lypsykarjalla ja matalimmat broilereilla) ja eläinryhmien sisällä (esimerkiksi sioille maksettava tuki on toimenpiteittäin

A) $\quad 1,76$ euroa/eläinyksikkö

B) $\quad 10,58$ euroa/eläinyksikkö

C) $\quad 8,83$ euroa/eläinyksikkö

D) 5,30 euroa/eläinyksikkö

E) $\quad 8,83$ euroa/eläinyksikkö), eikä kaikkien tukien suuruutta voida tilanpuutteen vuoksi raportoida tässä yksityiskohtaisesti.

Kastilian ja Léonin itsehallintoalueella Espanjassa eläinten hyvinvointitoimenpiteet on jaoteltu kanoihin, broilereihin sekä tehotuotannossa kasvatettuihin emakoihin kohdistuviin toimenpiteisiin. Kukin kolmesta toimenpiteestä koostuu perus- ja lisäsitoumuksesta. Lisäsitoumusta ei tarvitse täyttää heti. Esimerkiksi perussitoumuksen mukaan kanalle on varattava tilaa häkkikanalassa vähintään $825 \mathrm{~cm}^{2}$. Häkkikanaloiden lisäsitoumus sisältää vaatimuksia luonnonvalosta ja ilmanvaihdon järjestämisestä. Kanoihin kohdistuvan hyvinvointitoimenpiteen perustukitaso on 30-50 euroa/eläinyksikkö, broilereihin kohdistuvan toimenpiteen perustukitaso on 40-60 euroa/eläinyksikkö ja emakoihin kohdistuvan toimenpiteen perustukitaso on 100 euroa/eläinyksikkö. Perustukitasoja korjataan tilakohtaisesti eläinmääräkertoimilla siten, että tilan suuri eläinmäärä pienentää maksettavaa tukea.

Mecklenburg-Etu-Pommerin osavaltiossa Saksassa eläinten hyvinvointituki koostuu neljästä valinnaisesta toimenpiteestä:

1) nautojen kesälaidunnus

2) nautojen ja sikojen pitäminen pihatossa ja laiduntaminen

3) nautojen ja sikojen pitäminen oljilla kuivitetussa pihatossa

4) nautojen ja sikojen pitäminen oljilla kuivitetussa pihatossa, jossa on ulkoilumahdollisuus Toimenpiteet sisältävät eläinten tilavaatimuksia ja vaatimuksia laidunnusintensiteetistä. Esimerkiksi neljännen toimenpiteen tukitasot ovat: lypsylehmille 54 euroa/eläinyksikkö, emolehmille 53 euroa/eläinyksikkö, lihanaudoille 183 euroa/eläinyksikkö, lihasioille 129 euroa/eläinyksikkö ja emakoille 158 euroa/eläinyksikkö.

Skotlannin eläinten hyvinvointitoimenpide koostuu kahdesta ohjelmaan sitoutuneille pakollisesta toimenpiteestä jotka sisältävät eläinten hyvinvointisuunnitelman ja neljästä vapaaehtoisesta 
lisätoimenpiteestä. Pakolliset toimenpiteet ovat:

i) eläinten hyvinvointisuunnitelma - ennakoivan suunnitelman tekeminen hoitotoimenpiteiden käytöstä (Toimenpide sisältää opastuksen eläinlääketieteellisten tietojen ja hoitojen käytössä)

ii) eläinten hyvinvointisuunnitelma - ennakoivan suunnitelman tekeminen rokotteiden ja tavallisten lääkkeiden käytöstä

Tukitason laskentaperuste poikkeaa muista, sillä pakollisten toimenpiteiden tukitaso on tilakohtainen 390 euroa/tila. Vapaaehtoiset toimenpiteet ovat:

iii) vertailuanalyysi

iv) bioturvallisuussuunnitelman tekeminen

v) näytteenotto sairauksien/kunnon määrittämiseksi

vi) rehuanalyysi

\section{Johtopäätökset}

Vapaaehtoisen eläinten hyvinvointitoimenpiteen tarkoituksena on kaikissa tarkastelluissa maissa tuotantoeläinten hyvinvoinnin ja terveyden lisääminen sekä eläinten hyvinvointiin ja terveyteen liittyvien julkishyötyjen tuottaminen.

Eläinten hyvinvointia parantavat toimenpiteet nostavat lähes aina tuotantokustannuksia. Tästä syystä eläinten hyvinvointituella korvataan viljelijöille hyvinvoinnin tuottamisesta aiheutuneet lisäkustannukset ja tulonmenetykset ja joissakin maissa - kuten esimerkiksi Suomessa - myös viljelijöiden transaktiokustannukset. Tuen avulla pyritään varmistamaan, että kotieläintuotannon kannattavuus ja kansainvälinen kilpailukyky eivät heikkene eläinten hyvinvointia edistävien toimenpiteiden seurauksena.

Eläinten hyvinvoinnin edistämisellä pystytään entistä paremmin vastaamaan kuluttajien odotuksiin. Toisaalta eläinten hyvinvointia lisäävät toimenpiteet ovat kaikissa tarkastelluissa maissa (osin tukijärjestelmän luonteesta johtuen) teknispainotteisia, eikä niillä pystytä vastaamaan niihin vaatimuksiin eläinten kohtelusta, joita eläinten oikeuksien puolustajat ovat esittäneet. Tuotantoeläinten hyvinvointituen tyyppiset tukijärjestelmät ovat kuitenkin askel tähän suuntaan, ja on tärkeää jatkaa niiden edelleen kehittämistä.

\section{Kirjallisuus}

Kaustell, K. 2000. Ihmisen ja eläimen välinen vuorovaikutus. Teoksessa: Mälkiä, P., Ahlfors, K. \& Teräväinen, H. (toim.) Tuotantoeläinten hyvinvointi. Tieto tuottamaan 81. Maaseutukeskusten Liiton julkaisuja no 954: 24-28.

Raussi, S. \& Hänninen, L. 2005. Ihmisen ja tuotantoeläimen suhde. Teoksessa: Valros, A., Teräväinen, H. \& Helin, J. (toim.) Hyvinvoiva tuotantoeläin. Tieto tuottamaan 109. ProAgria Maaseutukeskusten Liiton julkaisuja nro 1014 : 27-34.

Valros, A. 2005. Eläimen käyttäytyminen ja hyvinvointi. Teoksessa: Valros, A., Teräväinen, H. \& Helin, J. (toim.) Hyvinvoiva tuotantoeläin. Tieto tuottamaan 109. ProAgria Maaseutukeskusten Liiton julkaisuja nro 1014: $22-26$.

Valros, A., Holma, U., Saloniemi, H. \& Korhonen, T. 2005. Mitä eläinten hyvinvoinnilla tarkoitetaan? Teoksessa: Valros, A., Teräväinen, H. \& Helin, J. (toim.) Hyvinvoiva tuotantoeläin. Tieto tuottamaan 109. ProAgria Maaseutukeskusten Liiton julkaisuja nro 1014: 4-17. 